\title{
Steroid effects on human endometrial glycoprotein biosynthesis
}

\author{
Carol Lambadarios, Cetra Hastings, J. Abo-Darub and I. D. Cooke \\ Department of Obstetrics and Gynaecology, University of Sheffield, \\ Jessop Hospital for Women, Leavygreave Road, Sheffield S3 7RE, U.K.
}

\begin{abstract}
Summary. Human endometrium from the secretory phase of the menstrual cycle was incubated with ${ }^{3} \mathrm{H}$ - and ${ }^{14} \mathrm{C}$-labelled glucosamine and $\left[{ }^{3} \mathrm{H}\right]$ leucine. Incorporation into secreted extracellular glycoprotein and accumulation of the label into the microsomal fraction were measured. When oestradiol or progesterone were added to the medium, medroxyprogesterone acetate (MPA), ethynodiol diacetate and chlormadinone acetate reduced incorporation of glucosamine and MPA reduced incorporation of leucine into glycoprotein. MPA reduced the amount of glucosamine in the microsomal fraction and also had an effect on amino acid transport within the endometrial cells, as indicated by intracellular $\alpha$-aminoisobutyric acid space measurements. These results and the ratios of ${ }^{3} \mathrm{H}$ and ${ }^{14} \mathrm{C}$ in the microsomal fraction and secreted protein suggest that MPA has a primary effect in decreasing amino sugar incorporation and a secondary effect in reducing amino acid incorporation into glycoprotein.
\end{abstract}

\section{Introduction}

The histology of human endometrial glandular cell secretion has been described by Noyes, Hertig \& Rock (1950). During the secretory phase the Golgi complexes are greatly developed and the distended endoplasmic reticulum contains glycogen and glycoprotein (Wynn \& Harris, 1967; Wynn \& Woolley, 1967). Pincus, Rock \& Garcia (1958) reported alterations in endometrial histology in response to synthetic progestagens. Flowers, Wilborn \& Enger (1974) studied the ultrastructure of the endometrium after treatment with quingestanol acetate for 3 months and observed that many aspects of protein synthesis were affected and that, despite ovulation, subnuclear vacuolation did not occur. They inferred from histochemical studies that the progestagen did not alter transport mechanisms across the cell surfaces, but that there was a reduction in the glycoprotein in the cells and that intracellular transport systems were affected. The histochemical and histological effects of oestradiol and progesterone on human endometrium in culture have been studied by Csermely, Demers \& Hughes (1969) and Kohorn \& Tchao (1969). Shapiro \& Hagerman (1974) examined precursor uptake into protein and RNA. This paper examines the effects of the progestagens, medroxyprogesterone acetate, ethynodiol diacetate, and chlormadinone acetate, on glycoprotein synthesis by human endometrium in culture to elucidate further the mechanism of action of these potent antifertility agents.

\section{Materials and Methods}

\section{Chemicals}

The radiochemical purity of $\left[1-{ }^{14} \mathrm{C}\right] \mathrm{D}$-glucosamine hydrochloride (sp. act. $55 \cdot 0 \mathrm{mCi} / \mathrm{mmol}$ ), $\left[1-{ }^{3} \mathrm{H}\right] \mathrm{D}$-glucosamine hydrochloride (sp. act. $2 \cdot 6 \mathrm{Ci} / \mathrm{mmol}$ ), $\left[4,5-{ }^{3} \mathrm{H}\right] \mathrm{L}-$ leucine (sp. act. $19 \mathrm{Ci} / \mathrm{mmol}$ ), $\left[1-{ }^{14} \mathrm{C}\right] 2 \alpha$-aminoisobutyric acid (sp. act. $58 \mathrm{mCi} / \mathrm{mmol}$ ) and $\left[1-{ }^{3} \mathrm{H}\right] \mathrm{D}$-sorbitol (sp. act. $5 \cdot 44 \mathrm{Ci} / \mathrm{mmol}$ ) was more than $99 \%$ and the chemicals were used as purchased from the Radiochemical Centre, Amersham. 
The steroids used were: oestradiol-17ß (1,3,5, (10)-estratriene-3,17ß-diol: Sigma Chemical Co., St Louis, Missouri); progesterone (4-pregnene-3,20-dione: Sigma); medroxyprogesterone acetate (17 $\alpha$-acetoxy, 6 $\alpha$-methyl-4-pregnene-3,20-dione (MPA): Upjohn Co., Kalamazoo, Michigan); ethynodiol diacetate (19-nor-17 $\alpha$-ethinyl-4-androstene-3,17 $\beta$-diol diacetate (ED): G. D. Searle and

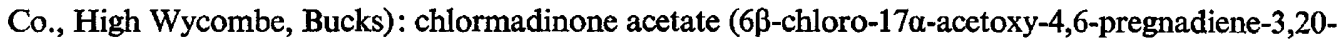
dione (CA): Syntex Pharmaceuticals Ltd, Maidenhead, Berks) and norethisterone (17 $\alpha$-ethinyl17ß-hydroxy-19-nor-4-androsten-3-one: Syntex). Radioactive steroids were: $\left[2,4,6,7-{ }^{3} \mathrm{H}\right]$ oestradiol (sp. act. $100 \mathrm{Ci} / \mathrm{mmol}$, Radiochemical Centre); $\left[1,2,{ }^{3} \mathrm{H}\right]$ progesterone (sp. act. $41 \mathrm{Ci} / \mathrm{mmol}$; Radiochemical Centre); [6,7- $\left.{ }^{3} \mathrm{H}\right]$ ethynodiol diacetate (sp. act. $81 \cdot 2 \mathrm{mCi} / \mathrm{mmol}$ : Searle); $\left[7 \alpha-{ }^{3} \mathrm{H}\right] \mathrm{medroxy}-$ progesterone acetate (sp. act. $30 \mathrm{mCi} / \mathrm{mmol}: \mathrm{Upjohn}$ ) and $\left[1{ }^{3} \mathrm{H}\right] \mathrm{ch} /$ ormadinone acetate (sp. act. $10 \cdot 3$ $\mathrm{Ci} / \mathrm{mmol}$ : Syntex).

The purity of all steroids was checked by thin-layer chromatography in three systems.

\section{Culture system}

Human endometrium was obtained by curettage performed incidental to another procedure such as tubal ligation, cautery of the cervix or dilatation for dysmenorrhoea, when it was anticipated that the endometrium would be normal. Specimens obtained at hysterectomy were also utilized. The tissue was immediately placed in cold saline under sterile conditions and transported to the laboratory. A sample was taken for routine histology; abnormal tissues were discarded and only results from normal tissues are presented.

Medium T199 was used as purchased (Biocult Labs, Glasgow) but all other solutions were sterilized by passing through a Millipore filter $(0.22 \mu \mathrm{m}$ pore size). The tissue was set up immediately in organ culture (Trowell, 1959), each culture containing 8-10 $2 \mathrm{~mm}^{3}$ explants. The explants were placed in the culture dishes (Falcon Plastics, Los Angeles) on lens paper supported on a grid over a central well containing $1 \mathrm{ml}$ medium T199 with $10 \%$ calf serum (Biocult), 200 units penicillin (Glaxo Labs, London), $100 \mu \mathrm{g}$ streptomycin (Glaxo) and $40 \mu \mathrm{g}$ insulin (B.P., Weddel Pharmaceuticals, London). The cultures were placed in sealed boxes, gassed with $95 \% \mathrm{air}, 5 \% \mathrm{CO}_{2}$ and incubated at $37^{\circ} \mathrm{C}$. One culture dish was maintained for a histological control. The phenol red in the T199 was used to indicate the need for re-gassing during the course of the experiment.

\section{Extraction of glycoprotein}

Glycoprotein was extracted from $1 \mathrm{ml}$ incubation medium aspirated from the culture dish, using ice-cold $10 \%$ trichloracetic acid solution. The precipitate was washed three times with $1 \mathrm{ml}$ $5 \%$ trichloracetic acid, twice with $1 \mathrm{ml}$ chloroform:methanol $(2: 1, \mathrm{v} / \mathrm{v})$; twice with $2 \mathrm{ml}$ acetone and twice with $1 \mathrm{ml}$ ether (Molnar, Robinson \& Winzler, 1965). The ether was evaporated and the residue solubilized for counting overnight with $0.3 \mathrm{ml}$ hyamine hydroxide 10X (Packard Instrument Co., Illinois) at $55^{\circ} \mathrm{C}$. Protein determinations were performed on $0.1 \mathrm{ml}$ homogenate by the method of Lowry, Rosebrough, Farr \& Randall (1951).

\section{Preparation of the microsomal fraction}

After the incubations were terminated and the media removed for glycoprotein precipitation, the explants were washed twice with $1 \mathrm{ml}$ ice-cold $0.9 \% \mathrm{NaCl}$ to remove any adhering medium. The excess fluid was removed by blotting and the explants homogenized in approximately $1 \mathrm{ml}$ icecold $0.25 \mathrm{M}$-sucrose in a $180-\mathrm{mm}$ A.G. tissue grinder. The homogenate was made up to $5 \mathrm{ml}$ with $0.25 \mathrm{M}$-sucrose and then centrifuged at $800 \mathrm{~g}$ for $15 \mathrm{~min}$. The supernatant was decanted and centrifuged at $105,000 \mathrm{~g}$ for $36 \mathrm{~min}$. The supernatant was again decanted to obtain the microsomal pellet which was gently resuspended in $0.1 \mathrm{ml}$ distilled water, transferred to a test-tube with a further $0.1 \mathrm{ml}$ distilled water and was solubilized for counting by the addition of $0.8 \mathrm{ml}$ hyamine hydroxide $10 \mathrm{X}$ and incubated overnight at $55^{\circ} \mathrm{C}$.

Representative microsomal pellets were fixed in $3 \%$ glutaraldehyde, washed in $0 \cdot 1 \mathrm{M}$-phosphate buffer, embedded in epoxy resin and sectioned at 60-90 nm. Examination with an AEI 6B electron 
microscope at $60 \mathrm{kV}$ at a final magnification of 30,000 showed a membrane preparation without nuclear or mitochondrial contamination.

\section{Conditions of counting}

The extract solubilized in hyamine hydroxide $10 \mathrm{X}$ was transferred to a counting vial; $0.2 \mathrm{ml}$ hyamine hydroxide $10 \mathrm{X}$ washings were also transferred and $15 \mathrm{ml}$ Bray's solution added (Bray, 1960). Counting was performed in either a Nuclear Chicago Mark I or Mark II Liquid Scintillation Counter. A quench correction was made by the addition of an internal standard or by channels ratio with an external standard. Counting times were such as to achieve less than $2 \%$ error.

\section{Oxygen consumption measurements}

Cultures were used after incubation for 0-4 days and 3 cultures were pooled to provide enough tissue for the electrode system. The tissue was blotted and placed in a reservoir containing fresh medium. This was gassed for $5 \mathrm{~min}$, the gas shut off and the electrode placed in contact with the surface of the medium. With continuous gentle stirring to eliminate pockets of deoxygenated medium, the electrode was removed after a 15-min reading; the tissue was then dried to constant weight. In control runs medium only was placed in the reservoir. The measurements were carried out in a Y.S.I. Model 53 oxygen monitor (Yellow Springs Instrument Co. Ltd, Yellow Springs, Ohio).

\section{Anaerobic cultures}

Cultures were placed in a Gaspack chamber (Becton-Dickinson U.K. Ltd, Wembley, Middlesex) which took $1.5 \mathrm{hr}$ to become anaerobic.

\section{Amino acid transport}

The measured total aminoisobutyric acid space, the extracellular (sorbitol) space, and the derived intracellular aminoisobutyric acid space were calculated as described by Roskoski \& Steiner (1967).

\section{Results}

\section{Cultures without added steroids}

After equilibration of cultures for $16 \mathrm{hr}$, the medium was replaced and to each culture dish was added $2 \cdot 5 \mu \mathrm{Ci}\left[1-{ }^{14} \mathrm{C}\right] \mathrm{D}$-glucosamine. The cultures were terminated in pairs after $4,8,16,24$ and $48 \mathrm{hr}$, glycoprotein extracts were prepared from the media, microsomal preparations were made and the protein concentration of each dish was determined (Table 1). When the cultures of endometrium were exposed to an excess of glucosamine the uptake onto the microsomes was almost linear for $8 \mathrm{hr}$ and then reached a plateau. Incorporation into the secreted glycoprotein reached a peak at $16 \mathrm{hr}$, was followed by a plateau, and then resumed activity, which in other experiments continued until $72 \mathrm{hr}$ or more (Cooke, Hastings \& Lambadarios, 1971). The results of adding $2 \mu \mathrm{Ci}$ $\left[4,5-{ }^{3} \mathrm{H}\right] \mathrm{L}$-leucine and terminating the cultures in pairs after $1,2,3,4,8,16$ and $24 \mathrm{hr}$ are shown in Table 1.

\section{Tissue viability during culture}

After equilibration at $1,4,8,16$ and $24 \mathrm{hr}$, paired cultures were given $2 \cdot 5 \mu \mathrm{Ci}\left[1-{ }^{14} \mathrm{C}\right] \mathrm{D}$-glucosamine and harvested $2 \mathrm{hr}$ later. Glycoprotein extracts and microsomal preparations were made and the protein concentration of the tissue determined. Peak glycoprotein production ( $680 \mathrm{~d} / \mathrm{min} / \mathrm{mg}$ protein) 
Table 1. Incorporation of $\left[{ }^{14} \mathrm{C}\right]$ glucosamine and $\left[{ }^{3} \mathrm{H}\right]$ leucine (d/min/mg protein) onto microsomes and into secreted glycoprotein of human secretory endometrium in organ culture without added steroids

\begin{tabular}{|c|c|c|c|c|c|c|c|c|c|c|c|}
\hline & \multicolumn{5}{|c|}{$\left[{ }^{14} \mathrm{C}\right]$ glucosamine } & \multicolumn{6}{|c|}{$\left[{ }^{3} \mathrm{H}\right]$ leucine } \\
\hline & \multicolumn{5}{|c|}{ Incubation time (hr) } & \multicolumn{6}{|c|}{ Incubation time (hr) } \\
\hline & 4 & 8 & 16 & 32 & 48 & 1 & 2 & 4 & 8 & 16 & 24 \\
\hline Microsomes & $\begin{array}{l}2200 \\
3000\end{array}$ & $\begin{array}{l}4900 \\
6100\end{array}$ & $\begin{array}{l}6600 \\
7200\end{array}$ & $\begin{array}{l}7210 \\
7296\end{array}$ & $\begin{array}{l}7200 \\
8060\end{array}$ & $\begin{array}{l}2600 \\
3000\end{array}$ & $\begin{array}{l}2700 \\
4600\end{array}$ & $\begin{array}{l}3400 \\
8000\end{array}$ & $\begin{array}{l}6800 \\
8200\end{array}$ & $\begin{array}{l}23,000 \\
51,000\end{array}$ & $\begin{array}{l}27,500 \\
54,100\end{array}$ \\
\hline Glycoprotein & $\begin{array}{r}990 \\
1110\end{array}$ & $\begin{array}{l}1500 \\
2000\end{array}$ & $\begin{array}{l}8000 \\
9000\end{array}$ & $\begin{array}{l}10,150 \\
10,250\end{array}$ & $\begin{array}{l}25,200 \\
30,300\end{array}$ & $\begin{array}{l}1200 \\
1700\end{array}$ & $\begin{array}{l}1000 \\
2100\end{array}$ & $\begin{array}{l}1800 \\
3400\end{array}$ & $\begin{array}{l}4300 \\
6000\end{array}$ & $\begin{array}{l}6200 \\
9500\end{array}$ & $\begin{array}{r}6200 \\
11,000\end{array}$ \\
\hline
\end{tabular}

occurred at $4 \mathrm{hr}$ so it is unlikely that medium glycoprotein was derived from cell leakage, which would have increased with time.

As a further confirmation of viability in culture, oxygen consumption measurements were carried out on fresh tissue and tissue that had been in culture for 1-4 days in samples obtained at different times of the menstrual cycle. Basal consumption was $3.6-4.2 \mu \mathrm{l} / \mathrm{hr} / \mathrm{mg}$ and the consumption on each day expressed as a mean ( \pm S.E.M.) \% of zero time was: Day 1, 118 $\pm 38,(n=4)$; Day $2,138 \pm 21$ $(n=4)$; Day 3, 194 $\pm 92(n=4)$; Day 4, 56 $\pm 11(n=4)$. Similar experiments showed that incorporation of $1.25 \mu \mathrm{Ci}\left[1-{ }^{14} \mathrm{C}\right] 2 \alpha$-aminoisobutyric acid was $<1000 \mathrm{~d} / \mathrm{min} / \mathrm{mg}$ protein throughout the $24 \mathrm{hr}$, excluding the possibility of contamination due to cell permeability and supporting the concept of active metabolism of the utilizable precursor by viable cells.

\section{Anaerobic cultures}

After equilibration for $16 \mathrm{hr}$ the medium was changed and $0.25 \mu \mathrm{Ci}\left[1-{ }^{14} \mathrm{C}\right] \mathrm{D}$-glucosamine and $2 \mu \mathrm{Ci}\left[4,5-{ }^{3} \mathrm{H}\right] \mathrm{L}$-leucine were added. Half the cultures were incubated aerobically while the other half were incubated anaerobically. After $24 \mathrm{hr}$ the cultures were harvested, glycoprotein and microsomal fractions prepared and protein concentrations measured for each dish. Under anaerobic conditions incorporation of both precursors was significantly reduced $(P<0.005$ for leucine incorporation into both fractions and $P<0.0005$ for glucosamine incorporation into both fractions), confirming the need for $\mathrm{O}_{2}$ and the active nature of incorporation of amino sugar and amino acid.

\section{Effect of steroid concentration}

Replicate cultures were set up for $72 \mathrm{hr}$ containing (i) $10^{-6} \mathrm{M}-\mathrm{MPA}$ and $10^{-6} \mathrm{M}$ oestradiol+progesterone; (ii) $10^{-9} \mathrm{M}-\mathrm{MPA}$ and $10^{-9} \mathrm{M}$ oestradiol+progesterone; (iii) $10^{-9} \mathrm{M}-\mathrm{MPA}$ and $10^{-6} \mathrm{M}$ oestradiol+progesterone; (iv) $10^{-6} \mathrm{M}-\mathrm{MPA}, 10^{-9} \mathrm{M}$ oestradiol+progesterone; (v) no steroids. A significant depression of glycoprotein production only occurred when $10^{-6} \mathrm{M}-\mathrm{MPA}$ was incubated in the presence of $10^{-9} \mathrm{M}$ oestradiol+progesterone $(9667 \pm 1000 \mathrm{~d} / \mathrm{min} / \mathrm{mg}$ versus $19,835 \pm 500 \mathrm{~d} / \mathrm{min} / \mathrm{mg}$ protein (control): $P<0 \cdot 005$ ).

\section{Addition of steroids}

Samples of endometrium from 11 different patients, some in the proliferative and some in the secretory phase, were set up for $72 \mathrm{hr}$ incubations. Samples of proliferative-phase tissue were set up as replicate dishes for the glucosamine control, the histology control, and added oestradiol, progesterone, oestradiol+progesterone, CA, MPA, ED, CA+oestradiol, MPA+oestradiol, or ED+oestradiol. Secretory-phase tissue was set up in replicate dishes as the glucosamine control, the histology control, and added oestradiol, progesterone, oestradiol+progesterone, CA+progesterone, MPA+ progesterone, $\mathrm{ED}+$ progesterone, $\mathrm{CA}+$ oestradiol+progesterone, MPA+oestradiol+progesterone, or ED+oestradiol+progesterone. The oestradiol and progesterone was used at a final concentration of $10^{-9} \mathrm{M}$ and CA, MPA and ED were used at a final concentration of $10^{-6} \mathrm{M}$. The results indicated that no proliferative-phase endometrium incorporated more than $2600 \mathrm{~d} / \mathrm{min} / \mathrm{mg}$ secreted protein, 


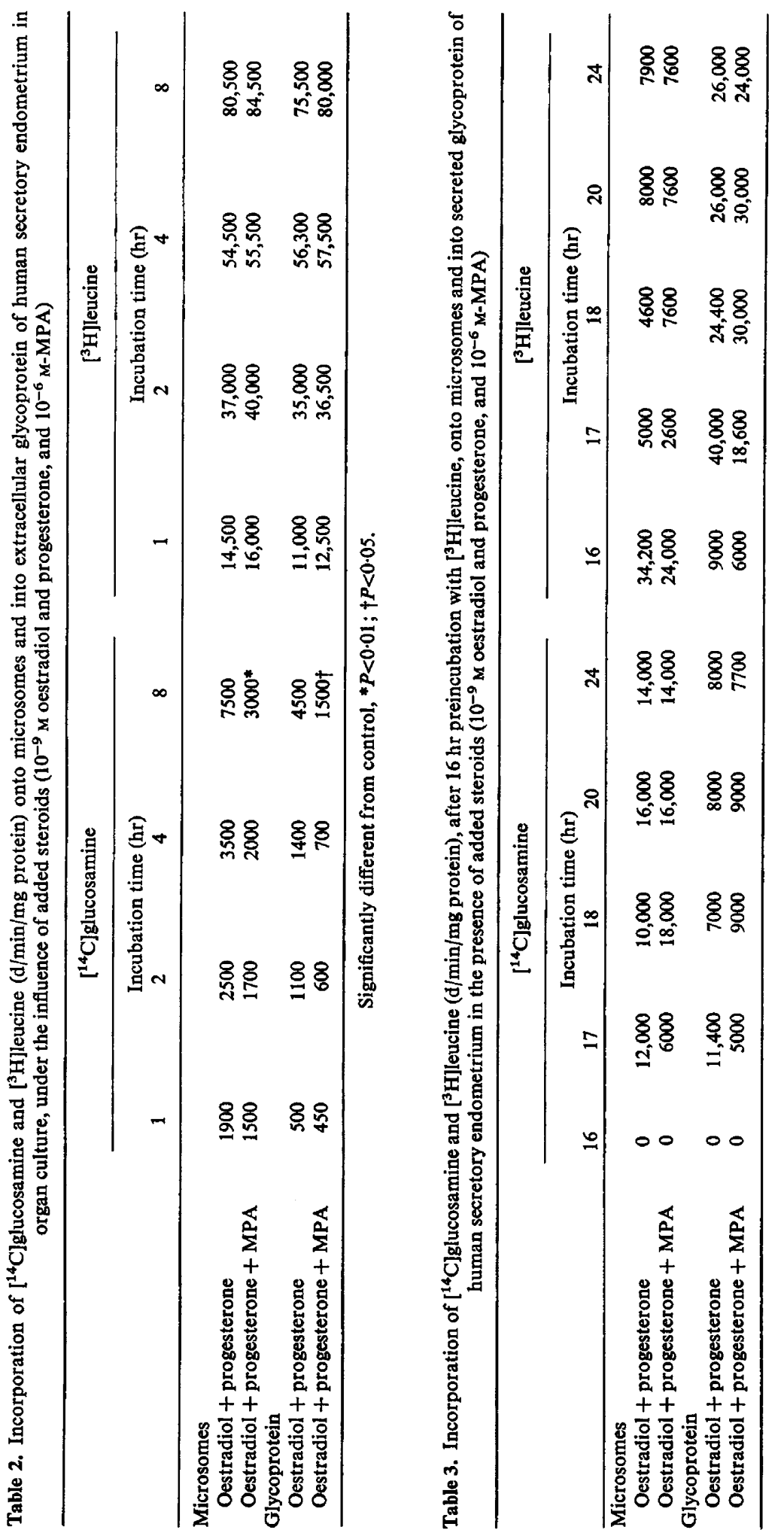


whereas secretory-phase endometrium incorporated up to $20,000 \mathrm{~d} / \mathrm{min} / \mathrm{mg}$ protein. Only in the cultures containing $10^{-9} \mathrm{M}$ oestradiol+progesterone and $10^{-6} \mathrm{M}$ progestagen with secretory-phase endometrium did significant depression of incorporation occur (CA, 776 versus $1900 \mathrm{~d} / \mathrm{min} / \mathrm{mg}$ protein: $P<0.005 ;$ MPA, 7672 versus $10,866 \mathrm{~d} / \mathrm{min} / \mathrm{mg}$ protein: $P<0.005 ; \mathrm{ED}, 10,283$ versus 14,690 $\mathrm{d} / \mathrm{min} / \mathrm{mg}$ protein $: P<0 \cdot 05$ ).

When $0 \cdot 25 \mu \mathrm{Ci}\left[1-{ }^{14} \mathrm{C}\right] \mathrm{D}$-glucosamine and $2 \mu \mathrm{Ci}\left[4,5-{ }^{3} \mathrm{H}\right] \mathrm{L}$-leucine were added to secretory-phase endometrium in the presence of $10^{-6} \mathrm{M}$ MPA and $10^{-9} \mathrm{M}$ oestradiol+progesterone (Table 2), MPA depressed the incorporation of $\left[{ }^{14} \mathrm{C}\right]$ glucosamine into the microsomal fraction $(P<0 \cdot 01)$ and secreted glycoprotein $(P<0.05)$. Incorporation of $\left[{ }^{3} \mathrm{H}\right]$ leucine into the secreted glycoprotein was depressed after $4 \mathrm{hr}(P<0 \cdot 01)$ but there was no effect on the incorporation into the microsomal fraction.

\section{Preincubation with $\left[{ }^{3} \mathrm{H}\right]$ leucine}

After equilibration for $16 \mathrm{hr}$, the medium bathing secretory-phase endometrium was changed and $2 \mu \mathrm{Ci}\left[{ }^{3} \mathrm{H}\right]$ leucine were added. The tissue was equilibrated for a further $16 \mathrm{hr}$ and the medium replaced by fresh medium containing $2 \mu \mathrm{Ci}\left[{ }^{3} \mathrm{H}\right]$ leucine and $0.25 \mu \mathrm{Ci}\left[{ }^{14} \mathrm{C}\right]$ glucosamine and steroids. Half the cultures were exposed to $10^{-9} \mathrm{M}$ oestradiol+progesterone and half to $10^{-9} \mathrm{M}$ oestradiol+progesterone and $10^{-6} \mathrm{M}$-MPA. Cultures were harvested at 1, 2, 4 and $8 \mathrm{hr}$. Glycoprotein was extracted, microsomal fractions prepared and protein content determined for each dish (Table 3). Since leucine is a component of basic cell structures and is incorporated more rapidly this was added first. On later addition of $\left[{ }^{14} \mathrm{C}\right] \mathrm{glucosamine}$ the incorporation of $\left.\left[{ }^{3} \mathrm{H}\right]\right]$ leucine into the microsomes fell sharply during the first hour and then remained at this low level. Incorporation of $\left[{ }^{3} \mathrm{H}\right]$ leucine into secreted glycoprotein rose dramatically $1 \mathrm{hr}$ after exposure to $\left[{ }^{14} \mathrm{C}\right]$ glucosamine. When MPA was present a similar picture was observed for the microsomes but the rise in incorporated [ $\left.{ }^{3} \mathrm{H}\right]$ leucine in glycoprotein was slower in the first hour. The incorporation of $\left[{ }^{14} \mathrm{C}\right]$ glucosamine into the microsomes rose sharply over the first hour and then reached a plateau. Incorporation into secreted glycoprotein reached a peak at $1 \mathrm{hr}$, then fell to a steady level. No changes were seen when MPA was present.

\section{Pulse-chase experiments}

Although $\left[{ }^{14} \mathrm{C}\right]$ glucosamine incorporation into secreted glycoprotein was depressed by $72 \mathrm{hr}$ after exposure of oestradiol, progesterone and progestagens, the timing of the onset of the depressive effect was not known. Preliminary experiments showed that depression was maximal within the first $24 \mathrm{hr}$ and later experiments that the incorporation was greatest within the first $8 \mathrm{hr}$.

Tissue was exposed to $1.25 \mu \mathrm{Ci}\left[{ }^{3} \mathrm{H}\right]$ glucosamine for $2 \mathrm{hr}$, the medium was removed, the tissue

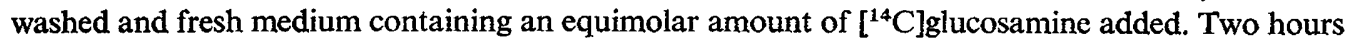
later the medium was removed, the tissue washed and $1 \mathrm{ml}$ medium without labelled glucosamine added. Oestradiol+progesterone $\left(10 \mu \mathrm{l}\right.$ at $\left.10^{-9} \mathrm{M}\right)$ and $10 \mu \mathrm{l}$ oestradiol+progesterone $\left(10^{-9} \mathrm{M}\right)$ and MPA $\left(10^{-6} \mathrm{M}\right)$ were added at zero time, and at 2 and $4 \mathrm{hr}$ the medium was replaced. Cultures were terminated in replicate after $1,2,3,4,5,6$ and $8 \mathrm{hr}$ of incubation.

Microsomal preparations, glycoprotein extractions and protein determinations were carried out

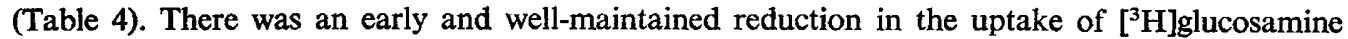
onto the microsomes in the presence of $10^{-6} \mathrm{M}$-MPA $(P<0.01)$. The chase of $\left[{ }^{14} \mathrm{C}\right] \mathrm{glucosamine}$ showed a depression $(P<0.01)$ after $4 \mathrm{hr}$. The uptake of precursor into glycoprotein was also considerably depressed by MPA as shown by the ${ }^{3} \mathrm{H}$-labelled $(P<0 \cdot 01)$ and the ${ }^{14} \mathrm{C}$-labelled pulses of glucosamine $(P<0.001)$ (Table 4). More $\left[{ }^{14} \mathrm{C}\right]$ glucosamine than $\left[{ }^{3} \mathrm{H}\right]$ glucosamine was taken up in the first hour of exposure.

\section{Ratio of $\left[{ }^{14} \mathrm{C}\right]$ glucosamine and $\left[{ }^{3} \mathrm{H}\right]$ leucine incorporation}

The presence of MPA lowered the ratio of glucosamine to leucine on the microsomes significantly $(P<0.0005)$ at $2-4 \mathrm{hr}$ (Table 5), indicating that less glucosamine than leucine was incorporated and this difference was maintained. The ratio of glucosamine to leucine in secreted glycoprotein was not 


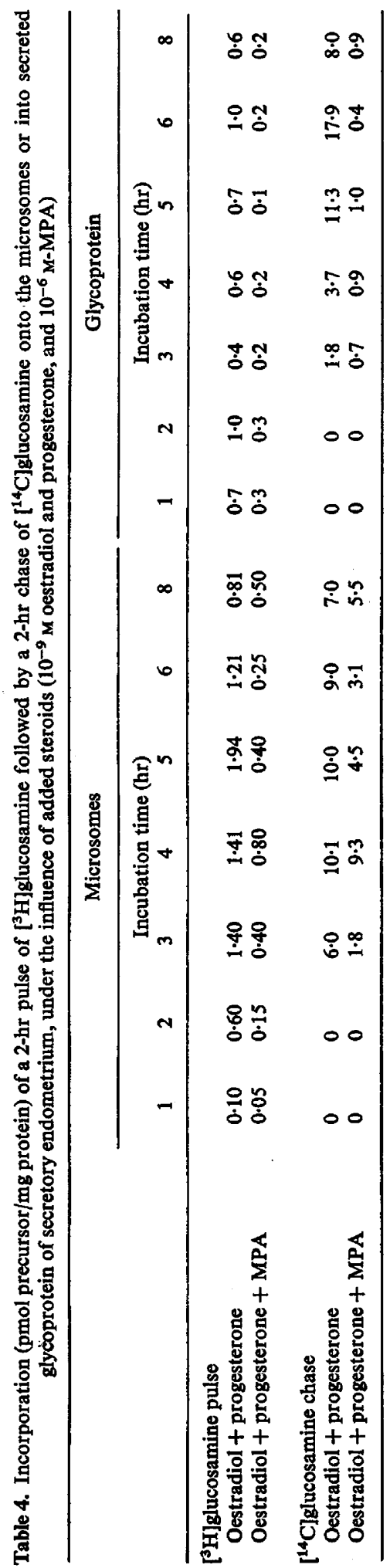


significantly altered up to $4 \mathrm{hr}$ by the presence of MPA, but from 4-8 hr there was a significant increase $(P<0.025)$.

Table 5. Ratio of incorporated $\left[{ }^{14} \mathrm{C}\right] g l u c o s a m i n e ~ t o ~\left[{ }^{3} \mathrm{H}\right]$ leucine onto microsomes and into secreted glycoprotein of human secretory endometrium, under the influence of steroids $\left(10^{-9} \mathrm{M}\right.$ oestradiol and progesterone, and $10^{-6}$ M-MPA)

\begin{tabular}{|c|c|c|c|c|c|c|c|c|}
\hline & \multicolumn{4}{|c|}{ Microsomes } & \multicolumn{4}{|c|}{ Glycoprotein } \\
\hline & \multicolumn{4}{|c|}{ Incubation time $(\mathrm{hr})$} & \multicolumn{4}{|c|}{ Incubation time $(\mathrm{hr})$} \\
\hline & 1 & 2 & 4 & 8 & 1 & 2 & 4 & 8 \\
\hline \multirow[t]{2}{*}{ Oestradiol + progesterone } & 1.36 & $1 \cdot 30$ & $1 \cdot 44$ & 0.7 & $0 \cdot 10$ & 0.36 & 0.76 & 0.22 \\
\hline & 1.44 & 1.46 & 1.66 & 0.8 & 0.21 & 0.50 & 0.86 & 0.31 \\
\hline \multirow[t]{2}{*}{ Oestradiol + progesterone + MPA } & $1 \cdot 22$ & 0.42 & 0.56 & 0.38 & 0.20 & $0 \cdot 10$ & 0.37 & $1 \cdot 30$ \\
\hline & $1 \cdot 32$ & $0.52^{*}$ & $0.70^{*}$ & 0.50 & $0 \cdot 32$ & $0 \cdot 20$ & 0.44 & $1.60 \dagger$ \\
\hline
\end{tabular}

Significantly different from control, ${ }^{*} P<0.0005 ; \nmid P<0.025$.

\section{Thin-layer chromatography of added steroids}

Endometrium from the secretory phase was equilibrated in culture and labelled oestradiol, progesterone, MPA, CA and ED were added to each dish. Cultures were terminated 1, 4, 8, 16, 24 and $48 \mathrm{hr}$ later. The media and the $105,000 \mathrm{~g}$ supernatant were collected and TLC performed. No metabolism of any steroid except oestradiol could be detected. Increase in the oestradiol metabolite increased with time: at $1 \mathrm{hr}, 0 \% ; 24 \mathrm{hr}, 33 \%$; and at $48 \mathrm{hr}, 50 \%$ in the medium; and at $1 \mathrm{hr}, 42 \%$; $24 \mathrm{hr}, 50 \%$; and $48 \mathrm{hr}, 67 \%$ in the cytosol. The metabolite appeared in the cytosol after $1 \mathrm{hr}$ but not in the medium until $4 \mathrm{hr}$. This suggests that the metabolite is being produced within the tissue and not formed by enzyme leakage into the medium. Chromatographic mobility in three systems (A, $\mathrm{C}$ and $\mathrm{K}$ of Lisboa \& Diczfalusy, 1965) suggested that the metabolite was oestrone, but no further identification was attempted. Cytosol levels of oestradiol, progesterone and the progestagens varied from $2 \cdot 0-7 \cdot 5 \%$ of the administered concentration. This was reached by $1 \mathrm{hr}$ and remained relatively constant for the remainder of the $48 \mathrm{hr}$ incubation. The uptake did not appear to vary with the day of the cycle.

\section{Amino acid transport}

After equilibration for $16 \mathrm{hr}$ the culture medium was changed and $0.5 \mu \mathrm{Ci}\left[1-{ }^{14} \mathrm{C}\right]$ minoisobutyric acid (AIBA) and $0.5 \mu \mathrm{Ci}\left[1-{ }^{3} \mathrm{H}\right] \mathrm{D}$-sorbitol with carrier $\mathrm{D}$-sorbitol to make a final concentration of $1.0 \mathrm{~mm}$ were added. Cultures were harvested at 1,4,8,16 and $24 \mathrm{hr}$. Some cultures received no steroids; others received $10^{-9} \mathrm{M}$ oestradiol+progesteroneand either $10^{-6} \mathrm{M}$-norethisterone or $10^{-6} \mathrm{M}-\mathrm{MPA}$. After harvesting, a $10 \mu \mathrm{l}$ sample medium and a $100 \mu$ sample homogenate (of total volume $5 \mathrm{ml}$ ) were taken for counting. Both samples were digested overnight at $55^{\circ} \mathrm{C}$ with $0.3 \mathrm{ml}$ hyamine hydroxide $10 \mathrm{X}$.

The measured total AIBA space, the extracellular (sorbitol) space and the derived intracellular AIBA space were calculated as described by Roskoski \& Steiner (1967):

$$
\begin{aligned}
\text { Total AIBA space }(\mu \mathrm{l} / \mathrm{mg} \text { protein }) & =\frac{{ }^{14} \mathrm{C} \mathrm{d} / \mathrm{min} / \mathrm{mg} \text { protein in homogenate }}{{ }^{14} \mathrm{C} \mathrm{d} / \mathrm{min} / \mu \mathrm{l} \text { medium }} \\
\text { Sorbitol space }(\mu \mathrm{l} / \mathrm{mg} \text { protein }) & =\frac{{ }^{3} \mathrm{H} \mathrm{d} / \mathrm{min} / \mathrm{mg} \text { protein in homogenate }}{{ }^{3} \mathrm{H} \mathrm{d} / \mathrm{min} / \mu \mathrm{l} \text { medium }}
\end{aligned}
$$

Since the extracellular space=the sorbitol space, intracellular AIBA space=total AIBA space-extracellular space.

The sorbitol or extracellular space showed no consistent alteration by MPA or norethisterone. The intracellular AIBA space was relatively constant in control cultures after the first hour. The progestagens however caused major fluctuations (Table 6), but the nature of the significant reductions and significant increases seen within a $24 \mathrm{hr}$ period is obscure. 


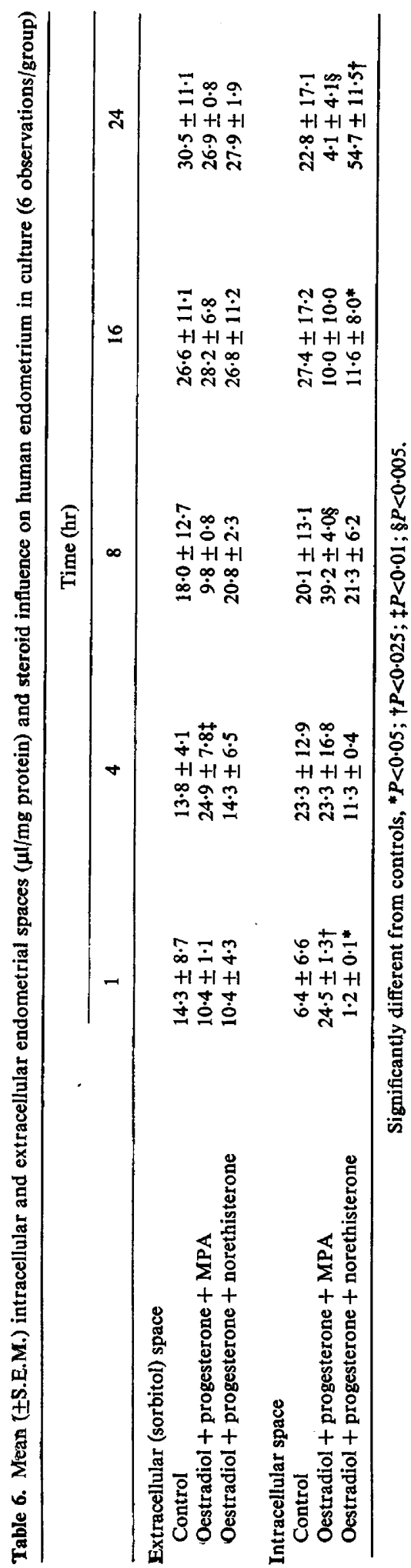


The ratio of intracellular AIBA space to extracellular AIBA space in control cultures exceeded unity from 4-16 hr. Since AIBA is not metabolized this may indicate that it is concentrated in the cell, entry occurring by means of an active process even though the changes were not striking. There were no consistent effects of MPA or norethisterone.

\section{Discussion}

The culture periods in these experiments varied from $16-96 \mathrm{hr}$ but $16 \mathrm{hr}$ was usual. Histological examination of tissue cultured for longer times sometimes showed necrotic changes, but this was less likely if the explants were kept small. The longer total incubation times also resulted in some tissue distortion due to PAS-positive material distending the interstices of the stroma. The explants became more friable and tended to grow into the matrix of the lens paper after long periods of culture; they were therefore difficult to remove and less tissue was recovered at these times. The tissue was, however, viable after long culture as partly friable explants still exhibited measurable oxygen consumption after 4 days of culture. The results obtained with anaerobic cultures also confirmed the validity of the culture system.

The concentrations of oestradiol and progesterone used in the experiments approach normal plasma levels and are similar to those used by Csermely et al. (1969) and Kohorn \& Tchao (1969). Pietras \& Szego (1975), using isolated rat endometrial cells, found that the same oestradiol concentration elicited a primary target cell action of sodium and water increments within $2 \mathrm{hr}$. The concentrations of the progestagens in the culture medium were probably higher than in plasma. Nash, Bopp, Shreve \& Schols (1971) reported that chlormadinone acetate reached a concentration of $10^{-8} \mathrm{M}(2 \mathrm{ng} / \mathrm{ml})$ in plasma after oral administration of contraceptive dosages, although Guerrero, Landgren, Montiel, Cekan \& Diczfalusy (1975) emphasized the discrepancy between plasma and endometrial levels of endogenous steroids which were up to 20 -fold greater in the tissue and mostly higher in the proliferative phase.

Sweat \& Bryson (1970) have demonstrated metabolism of progesterone in human endometrium, but no major metabolic product was identified in the present experiments, presumably because of the very small amounts of tissue incubated. Metabolic products of the synthetic progestagens have not been identified. Sweat, Bryson \& Young (1967) and Gurpide \& Welch (1969) have shown that oestradiol is extensively converted to oestrone in human endometrium.

The CA, MPA and ED were only added to proliferative-phase tissue with oestradiol since this would have been the steroid to which the tissue had been exposed in vivo. Similarly, secretory-phase tissue had been exposed to oestradiol and progesterone in vivo. The fact that the $72 \mathrm{hr}$ culture of secretory tissue showed a depression of incorporation into secreted glycoprotein when CA, MA and ED were added with oestradiol and progesterone, but not when oestradiol or progesterone or the synthetic progestagens alone were used, suggests a competitive mode of action by the progestagens.

MPA had an effect on the amino acid and amino sugar components of glycoprotein. The effect was first seen at $2 \mathrm{hr}$ as impaired uptake of glucosamine onto microsomes, but was no longer present at $8 \mathrm{hr}$. Leucine uptake onto microsomes was not influenced, but leucine uptake into glycoprotein was reduced at $8 \mathrm{hr}$. The absence of depression of microsomal leucine uptake suggests that leucine also acts as a precursor for many other structural proteins that are not influenced by this progestagen. Glucosamine incorporation into secreted glycoprotein was more obviously influenced by the progestagens; reduction in glucosamine incorporation occurred from $2 \mathrm{hr}$ but did not have a critical effect on leucine incorporation until $8 \mathrm{hr}$ (Tables 2 and 5). Sugar residues in glycoprotein are probably added after the polypeptide has been synthesized and released from the ribosomes, although a small amount of bound glucosamine probably occurs in nascent polypeptides (Ginsberg \& Neufeld, 1969). However, available glucosamine must be critical for continued completion of the polypeptide chain, as shown by the results of leucine preincubation in the absence of glucosamine (Table 3) and in the reduction of leucine incorporation seen at $8 \mathrm{hr}$ (Table 2). The effect on leucine incorporation was striking, as shown by the increased ratio of incorporated glucosamine to leucine. If the only 
effect were a reduction in glucosamine, this ratio should not have risen. Since it rose significantly, the amino acid reduction must have been greater than the molar glucosamine reduction and there must have been an additional depressive effect on amino acid incorporation. This was not shown by a change in microsomal ratio, probably because it was masked by leucine taken up for synthesis of structural proteins. The primary effect therefore of MPA and perhaps the other progestagens is a reduction of the microsomal amino sugar uptake, and hence of passage through into secreted glycoprotein, and a secondary reduction in amino acid incorporation into glycoprotein because this is critically dependent on an adequate supply of amino sugar. Long-term administration of steroids would probably result in a progesssive reduction in glycoprotein synthesis.

The depressive effects of MPA first noted on the endoplasmic reticulum may influence the quantity and, by changes in precursor ratio, the quality of secretion and it could result in the histological abnormalities described by Flowers et al. (1974). Thus specific endometrial glycoproteins, such as blastokinin (Krishnan \& Daniel, 1967) which may have an important role in implantation (Arthur \& Daniel, 1972), may be altered or critically reduced, resulting in potent antifertility effects of these progestagens by a local action quite apart from any suppression of ovulation.

The pulse-chase experiments showed that the progestagen effect occurred rapidly and was first seen at the microsomal level. The apparently anomalous point at $4 \mathrm{hr}$ (Table 4) was frequently observed and this and the surprisingly rapid uptake of glucosamine after leucine preincubation may suggest that acute changes in medium concentration of precursor influenced the subsequent rate of uptake. Other experiments showing continuous exposure to labelled glucosamine did not show a sudden increase in uptake between 3 and $4 \mathrm{hr}$. The stimulatory effect of oestradiol and progesterone has already been demonstrated (Cooke et al., 1971) and although the steroid cytosol content remains relatively constant over a $48 \mathrm{hr}$ period the addition of fresh oestradiol and progesterone with the chase label could exert a further stimulatory effect.

Sunshine, Williams \& Rabin (1971) and Blyth, Freedman \& Rabin (1971) suggested that oestradiol and testosterone may be bound on intracellular membranes and may activate them, but the binding affinity of synthetic progestagens for these membranes and hence their potential blocking action is unknown. MPA and norethisterone influenced the transport of amino acid within the cell during a $24 \mathrm{hr}$ period, but elucidation of the major fluctuations in space volumes requires further study. Oestradiol and progesterone have different effects on the components of endometrium, the glandular and luminal epithelial cells and the stromal cells, as shown by Tachi, Tachi \& Lindner (1972) in the rat, and Marcus (1974) in the guinea-pig. Human secretory-phase endometrium contains a large proportion of glandular cells; since secreted glycoprotein was assessed in the present study it is likely that the results refer principally to the action of progestagens on the glandular cells.

Mr Gari Sage and Miss Linda Thornton of the Tenovus Institute, Cardiff gave excellent assistance with the cultures when the early part of the work was carried out there, and we are grateful to Professor K. Griffiths for the use of the facilities. Dr R. Levin of the Department of Physiology, University of Sheffield kindly advised in the oxygen consumption studies. Medroxyprogesterone acetate was donated by Dr R. C. Thomas of Upjohn Co., Kalamazoo; ethynodiol diacetate by Dr J. Butler of G. D. Searle and Co., High Wycombe; chlormadinone acetate and norethisterone by Dr June Lawson of Syntex Pharmaceuticals, Maidenhead. Labelled steroids were gifts from the respective companies. The work was supported by a Tenovus Grant and an M.R.C. Fellowship to C.H. We are grateful to Mrs Valerie Pryor for typing the manuscript.

\section{References}

Arthur, A.T. \& Daniel, J.C., JR (1972) Progesterone regulation of blastokinin production and maintenance of rabbit blastocysts transferred into uteri of castrate recipients. Fert. Steril. 23, 115-122.
Blyth, C.A., Freedman, R.B. \& Rabin, B.R. (1971) Sex specific binding of steroid hormones to microsomal membranes of rat liver. Nature, New Biol. 222, 452-454. 
BRAY, G.A. (1960) A simple efficient liquid scintillator for counting aqueous solutions in a liquid scintillation counter. Analyt. Biochem. 1, 279-285.

Cooke, I.D., Hastings, C.D. \& Lambadarios, C. (1971) Organ culture studies in normal endometrium. In Symposium on Endometrial Cancer, pp. 23-30. Eds M. Brush, R. W. S. Taylor \& D. C. Williams. Heinemann, London.

Csermely, T., Demers, L.M. \& Hughes, E.C. (1969) Organ culture of human endometrium. Effects of progesterone. Obstet. Gynec., N. Y. 34, 252-259.

Flowers, C.E., Wilborn, W.H. \& ENGer, J. (1974) Effects of quingestanol acetate on the histology, histochemistry, and ultrastructure of the human endometrium. Am. J. Obstet. Gynec. 120, 589-612.

Ginsburg, V. \& Neufeld, E. F. (1969) Complex heterosaccharides of animals. A. Rev. Biochem. 38, 371387.

Guerrero, R., Landgren, B.M., Montiel, R., Cekan, Z. \& DiczFalusY, E. (1975) Unconjugated steroids in the human endometrium. Contraception 11, 169-177.

GuRPIDE, E. \& WelCh, M. (1969) Dynamics of uptake of estrogens and androgens by human endometrium. J. biol. Chem. 244, 5159-5169.

KohorN, E.I. \& TCHAO, R. (1969) Conversion of proliferative endometrium to secretory endometrium by progesterone in organ cuiture. $J$. Endocr. 45, 401-405.

KRISHNAN, R.S. \& DANIEL, J.C., JR (1967) 'Blastokinin': inducer and regulator of blastocyst development in the rabbit uterus. Science, N.Y. 158, 490-492.

Lisboa, B.T. \& DiczfalusY, E. (1965) Thin-layer chromatography of $\Delta^{4}-3$ oxosteroids of the androstene series. J. Chromatogr. 19, 81-104.

LoWry, O.H., Rosebrough, N.J., FARR, A.L. \& RANDALL, R.J. (1951) Protein measurements with the Folin-phenol reagent. J. biol. Chem. 193, 265-275.

Marcus, G.J. (1974) Hormonal control of proliferation in the guinea-pig uterus. J. Endocr. 63, 89-97.

MolNAR, J., RoBINSON, G.B. \& WINZLER, R.J. (1965) Biosynthesis of giycoproteins. IV. The subcellular sites of incorporation of glucosamine- $1-{ }^{14} \mathrm{C}$ into glycoprotein in rat liver. J. biol. Chem. 240, 18821888.
NASh, J.F., BopP, R.J., Shreve, R.W. \& Schols, N.E. (1971) A study of chlormadinone acetate concentrations in human plasma following the oral administration of tablets. Curr. Ther. Res. 13, 407-411.

Noyes, R.W., Hertig, A.T. \& Rock, J. (1950) Dating of the endometrial biopsy. Fert. Steril. 1, 3-25.

Pietras, R.J. \& Szego, C.M. (1975) Steroid hormoneresponsive, isolated endometrial cells. Endocrinology 96, 946-954.

Pincus, G., Rock, J. \& Garcia, C.R. (1958) Effects of certain 19-nor steroids upon reproductive processes. Ann. N. Y. Acad. Sci. 71, 677-690.

Roskoski, R., JR \& SteINeR, D.F. (1967) Effects of estrogen on amino acid transport in rat uterus. Biochim. biophys. Acta 35, 727-731.

Shapiro, S.S. \& Hagerman, D.D. (1974) Protein and RNA synthesis in human proliferative endometrium in organ culture and the effect of progesterone. J. Endocr. 62, 663-668.

Sunshine, G.H., Williams, D.J. \& Rabin, B.R. (1971) Role for steroid hormones in the interaction of ribosomes with the endoplasmic membranes of rat liver. Nature, New Biol. 230, 133-136.

SWEAT, M.C. \& BRYSON, M.J. (1970) Comparison of the metabolism of progesterone in proliferative human endometrium and myometrium. Am. $J$. Obstet. Gynec. 106, 193-201.

Sweat, M.C., Bryson, M.J. \& Young, R.B. (1967) Metabolism of $17 \beta$-estradiol and estrone by human proliferative endometrium and myometrium. Endocrinology 81, 167-172.

TACHI, C., TACHI, S. \& Lindner, H.R. (1972) Modification by progesterone of estradiol-induced cell proliferation, RNA synthesis and estradiol distribution in the rat uterus. J. Reprod. Fert. 31, 5976.

Trowell, 0 . (1959) The culture of mature organs in a synthetic medium. Expl Cell Res. 16, 118-147.

WYNN, R.M. \& HARRIS, J.A. (1967) Ultrastructural cyclic changes in the human endometrium. I. Normal preovulatory phase. Fert. Steril. 18, 632-648.

WYNN, R.M. \& WoolleY, R.S. (1967) Ultrastructural cyclic changes in the human endometrium. II. Normal post ovulatory phase. Fert. Steril. 18, 721-738.

Received 11 August 1975 